\title{
Gambogic Acid Induced Apoptosis through Activation of Caspase-dependent Pathway in Aortic Smooth Muscle Cells
}

\author{
Dae-Kwang Kim ${ }^{1,2}$, Tae-Jin $\mathrm{Lee}^{3}$, Eun-Ae Kim ${ }^{3}$, Ju Hwan Kang ${ }^{3}$, Kyung Gon Kim ${ }^{3}$, \\ Joo-Young $\mathrm{Kim}^{3}$ \\ ${ }^{1}$ Department of Medical Genetics, School of Medicine, Keimyung University \\ ${ }^{2}$ Hanvit Institute for Medical Genetics \\ ${ }^{3}$ Department of Anatomy, College of Medicine, Yeungnam University \\ (Received 27 June 2013, revised 6 August 2013, accepted 12 September 2013, Published Online 30 September 2013)
}

\begin{abstract}
Gambogic acid (GA) has powerful apoptotic actions. The authors investigated whether GA has apoptotic effects on aortic smooth muscle cells, and compared its potency with that of simvastatin.

Smooth muscle cells were isolated from the aortas of Sprague-Dawley rats (4-6 week). Cell purities were confirmed by IF staining using $\alpha$-smooth muscle actin antibody. The $\mathrm{IC}_{50}$ values for cell death by GA and simvastatin were determined using a MTT assay, and the apoptotic effects of $1 \mu \mathrm{M} \mathrm{GA}$ or $30 \mu \mathrm{M}$ simvastatin (concentrations correspond to $\mathrm{IC}_{50}$ values) were determined after $24 \mathrm{~h}$ of treatment using live cell images and by FITC annexin-V and propidium iodide double-staining. In addition, western blotting was used to evaluate apoptosis by quantifying reductions in the expression levels of the PARP and procaspase- 3 as well as cleavages of PARP and procaspase- 3 after treatment with $1 \mu \mathrm{M}$ GA or $30 \mu \mathrm{M}$ simvastatin. The $\mathrm{IC}_{50}$ of $\mathrm{GA}(1 \mu \mathrm{M})$ was lower than that of simvastatin $(30 \mu \mathrm{M})$. Cell numbers were markedly reduced by both drugs in live cell images. GA $(1 \mu \mathrm{M})$ produced a higher level of apoptosis than $30 \mu \mathrm{M}$ simvastatin $(26.4 \pm 2.37 \%$ vs. $8.3 \pm 1.54 \%$, respectively; $\mathrm{P}<0.05, \mathrm{n}=3)$ by FITC annexin-V \& PI double-staining. In addition, $1 \mu \mathrm{M}$ GA reduced the expressions of PARP, procaspase-3, and Mcl1 in cells, whereas $30 \mu \mathrm{M}$ simvastatin did not. Pretreatment with z-VAD-fmk attenuated GA-induced apoptosis and the cleavages of PARP and procaspase-3. The decreased level of Mcl-1 protein induced by GA treatment was recovered by z-VAD-fmk.

These results indicate that GA-induced apoptosis was mediated by a caspase-dependent pathway.
\end{abstract}

Keywords : Gambogic acid, Apoptosis, Smooth muscle cells, Simvastatin

\section{Introduction}

Atherosclerosis manifests as plaque build-up in arteries, and its multifactorial etiology has been shown to involve the activities of inflammatory cells, vascular smooth muscle cells (VSMCs), and intracellular and extracellular

\footnotetext{
*This research was supported by a grant of Yeungnam University Medica Center (2001)

The author (s) agree to abide by the good publication practice guideline for medical journals.

The author (s) declare that there are no conflict of interest.

Correspondence to : Joo-Young Kim (Department of Anatomy, College of Medicine, Yeungnam University, Daegu, Korea)

E-mail : jookim@med.yu.ac.kr
}

lipids [1-4].

The arterial wall is composed of three layers; the tunica intima, media, and adventitia. VSMCs of coronary arteries reside in the middle layer, and provide structural integrity to vessel walls and control vascular tone and blood pressure [5]. VSMCs also exhibit a contractile phenotype and low proliferative rates [6]. However, endothelial dysfunction and vessel wall injury during atherosclerosis result in the activation and dedifferentiation of arterial smooth muscle cells (SMCs) [5,7], and resultant intimal thickening provides the basis for the build-up of atherosclerotic plaque [8]. These processes are triggered by various cytokines and growth factors, including interleukin 1 beta (IL-1 $\beta$ ), 
interleukin 6 (IL-6), transforming growth factor beta 1 (TGF- $\beta 1$ ), tumor necrosis factor alpha (TNF- $\alpha$ ), thrombin, fibroblast growth factor (FGF), insulin-like growth factor 1 (IGF-1), platelet-derived growth factor (PDGF), urokinase plasminogen activator, angiotensin II, and vascular endothelial growth factor(VEGF), which are all expressionally upregulated in atherosclerotic lesions [9-12]. In the diseased state, VSMCs re-enter the cell cycle, proliferate, and migrate from tunica media to intima [13]. Furthermore, after vessel injury, intimal VSMCs adopt a synthetic phenotype, characterized by hyperplasia or hypertrophy and matrix protein accumulation in intima and/or media with or without lipid deposition, which in total, result in arterial wall thickening and stiffness $[14,15]$. The abnormal proliferation and migration of VSMCs in arterial walls are important factors in the development of atherosclerosis [15]. In particular, VSMC apoptosis has been proposed to play a significant role in the control of the thickening of intima and/or media [16].

Gambogic acid (GA), the main active ingredient of Gamboge hanburyi, is a representative oriental medicine, which has been used for its detoxifying, homeostatic, and anti-inflammatory properties for thousands of years [17]. Furthermore, the anticancer effect of GA has been attributed to its activation of impaired apoptosis pathways in cancerous cells via the down-regulation of telomerase [17]. Recent reports have shown that the molecular mechanism underlying the apoptotic effect of GA involves its interaction with transferrin receptor [18] and the subsequent suppression of the nuclear factor-kB signaling pathway [19]. Simvastatin is a cholesterol-lowering agent that is widely used for the treatment and prevention of atherosclerosis [20]. Furthermore, simvastatin has been reported to lower nitric oxide (NO) synthase expression and induce cell cycle arrest and apoptosis [21]. These observations suggest the actions of GA and simvastatin are related directly or indirectly with apoptosis. In addition, in a previous study, we found that SMCs were easily isolated using simple enzymatic method from the rat aortic wall at purities of $~ 90 \%$ [22].

In this study, we investigated whether GA has apoptotic effects on aortic SMCs, and subsequently, we compared its apoptotic effects with those of simvastatin. To examine the apoptotic effects of the two drugs, SMCs were isolated from Sprague-Dawley rats. Cell purities were determined by immunofluorescent (IF) staining using $\alpha$-smooth muscle actin ( $\alpha$-SMA) antibody, and the $\mathrm{IC}_{50}$ values of $\mathrm{GA}$ and simvastatin with respect to cell death were determined using a MTT (3-(4,5-dimethylthiazol-2-yl)-2,5-diphenyltetrazolium bromide) assay. The apoptotic effects of both drugs were examined by treating SMCs at half maximal inhibitory concentration $\left(\mathrm{IC}_{50}\right)$ levels and then analyzing live cell images and fluorescein isothiocyanate (FITC) annexin-V and propidium iodide (PI) double staining results. Levels of apoptosis-regulating proteins were determined by western blotting.

\section{Materials and Methods}

\section{Reagents}

Sprague-Dawley rats (4-6 week) were obtained from Samtaco Bio (Osan, Korea). Dulbecco's modified Eagle's medium $(\mathrm{DMEM}), 1 \times$ non-essential amino acids, $1 \times$ sodium pyruvate, $\mathrm{N}$-2-hydroxyethylpiperazine-N'-2-ethanesulfonic acid(HEPES), penicillin, streptomycin, trypsin-Ethylenediaminetetraacetic acid (EDTA), and fetal bovine serum (FBS) were purchased from Gibco (Grand Island, NY, USA). GA, simvastatin, MTT, heparin sodium salt, gelatin, dimethyl sulfoxide (DMSO), PI and 4',6-diamidino-2-phenylindole (DAPI) were from Sigma-Aldrich (Saint Louis, MO, USA). Normal goat serum (10\%), rat anti-rabbit $\alpha$-SMA, and FITC-conjugated goat anti-rat Immunoglobulin G(IgG) were from Zymed (Carlsbad, CA, USA). Fluorescent mounting medium was purchased from Dako Cytomation(UK), FITC annexin-V antibody from Abcam (UK), and BCA protein assay kits from Pierce (Los Angeles, CA, USA). Immobilon-P membranes and enhanced chemiluminescence (ECL) western blotting kits were obtained from Millipore (Hertfordshire, UK). Rabbit poly ADP-ribose polymerase (PARP) polyclonal antibodies were purchased from Cell signaling Technology (Boston, MA, USA). Rabbit procaspase-3 polyclonal antibodies were from Enzo Life Sciences (Farmingdale, NY, USA). Rabbit myeloid cell leukemia sequence 1 (Mcl-1) polyclonal antibody and rabbit $\beta$-Actin polyclonal antibody were from Santa Cruz Biotechnology (Santa Cruz, CA, USA). Benzyloxycarbonyl-Val-Ala-Asp (OMe)-fluoromethylketone (z-VAD-fmk) were from Calbiochem (San Diego, CA, USA).

\section{Isolation of aortic SMCs}

Aortic SMCs were isolated as we previously described 
[22]. Experiments were performed according to the guidelines of the Intramural Animal Use and Care Committee of the College of Medicine, Yeungnam University. Cells were harvested from aortic walls composed on only tunica media, and resuspended in DMEM containing 10\% FBS, counted, and then seeded at $1 \times 10^{4}$ cells $/ \mathrm{cm}^{2}$ in plastic culture dishes coated with gelatin.

\section{Maintenance of SMCs}

Plated cells were maintained in DMEM supplemented with 20\% FBS, L-glutamine, non-essential amino acids, sodium pyruvate, heparin sodium salt, HEPES, penicillin $(100 \mathrm{U} / \mathrm{mL})$, and streptomycin $(100 \mathrm{mg} / \mathrm{mL})$ in a humidified $95 \%$ air $/ 5 \% \mathrm{CO}_{2}$ incubator. These cells were grown in $100 \Phi$ plates, and then subcultured for no more than 5 passages. Cells were stored in nitrogen at $-196^{\circ} \mathrm{C}$, and used for experiments after thawing.

\section{IF staining against $\alpha$-SMA}

IF staining was performed as previously described [23]. Briefly, subcultured cells were seeded at $1 \times 10^{4}$ cells $/ \mathrm{cm}^{2}$ on cover glasses, and then fixed in 3.7\% paraformaldehyde solution. Rat anti-rabbit $\alpha$-SMA and FITC-conjugated goat anti-rat $\operatorname{IgG}$ antibodies were diluted at $1: 100$ and $1: 100$, respectively. Cytoplasmic $\alpha$-SMA expression was used to identify SMCs. Nuclei were counter-stained with DAPI. Cells were photomicrographed under a Leica DM 6000B fluorescent microscope (Wetzlar, Germany). Experiments were performed three times $(n=3)$.

\section{MTT assay and the $\mathrm{IC}_{50}$ values of $\mathrm{GA}$ and simvastatin}

Cell viabilities were evaluated using a MTT assay, as previously described [24]. MTT solution was prepared at $5 \mathrm{mg} / \mathrm{mL}$ in PBS and filtered through a $0.2 \mu \mathrm{m}$ filter immediately before use. To measure cell viabilities, subcultured cells were seeded into 24 -well plates at $5 \times 10^{4}$ cells per well and treated with $0,0.2,0.5,1$, or $5 \mu \mathrm{M}$ of GA or 0,1 , 5,30 , or $60 \mu \mathrm{M}$ of simvastatin for $24 \mathrm{~h}$. Briefly, $100 \mu \mathrm{L}$ (5 $\mathrm{mg} / \mathrm{mL}$ ) of MTT working solution were added to each well. Formazan crystals were dissolved in $100 \mu \mathrm{L}$ of DMSO, and well absorbances were measured at $570 \mathrm{~nm}$ using an ELISA Microplate Reader (BIO-TEK, Norcross, GA, USA). Results are expressed as relative viabilities (\%) versus non- treated controls. Cells numbers in each well were counted, and experiments were performed three times $(n=3)$.

\section{Live cell imaging}

Subcultured cells were seeded at $1 \times 10^{4}$ cells per well into 96 well plates before being treated with $1 \mu \mathrm{M}$ GA or $30 \mu \mathrm{M}$ simvastatin. Live cell images after $24 \mathrm{~h}$ of treatment were acquired using Leica DMIRE2 inverted microscope (Wetzlar, Germany).

\section{FITC annexin-V and PI double-staining}

Cellular DNA contents were assessed by flow cytometry. Subcultured cells were plated at $1 \times 10^{4}$ cells $/ \mathrm{cm}^{2}$ in $100 \Phi$ plates and treated with $1 \mu \mathrm{M}$ GA or $30 \mu \mathrm{M}$ simvastatin. Attached cells were collected using trypsin and $2.2 \mathrm{mmol} /$ L EDTA in PBS, mixed with the detached cells present in supernatants, and centrifuged. Cells were then rinsed with PBS, suspended in a solution containing $1.5 \mathrm{mg} / \mathrm{L}$ FITC annexin- $\mathrm{V}$ and $1.8 \mathrm{mmol} / \mathrm{L} \mathrm{CaCl}_{2}$ for $1 \mathrm{~h}$ at $37^{\circ} \mathrm{C}$, washed twice with PBS, and resuspended in a solution containing FITC annexin-V antibody for $30 \mathrm{~min}$ at $37^{\circ} \mathrm{C}$. Cells were then suspended in a solution containing $75 \mathrm{mmol} / \mathrm{L} \mathrm{PI}$, and analyzed using a FACScanner (Becton Dickinson, Franklin Lake, NJ, USA) and Cell Quest software. More than 10,000 cells were analyzed per sample. Experiments were performed three times $(n=3)$.

\section{Western blot}

Subcultured cells were plated at $1 \times 10^{4}$ cells $/ \mathrm{cm}^{2}$ in $100 \Phi$ plates, and treated with $1 \mu \mathrm{M} \mathrm{GA}$ or $30 \mu \mathrm{M}$ simvastatin for $24 \mathrm{~h}$. Cell lysates were prepared by suspending 5 $\times 10^{6}$ cells in $100 \mu \mathrm{L}$ of lysis buffer $(137 \mathrm{mM} \mathrm{NaCl}, 15 \mathrm{mM}$ ethylene glycol tetraacetic acid (EGTA), $0.1 \mathrm{mM}$ sodium orthovanadate, $15 \mathrm{mM} \mathrm{MgCl}_{2}, 0.1 \%$ Triton X-100, $25 \mathrm{mM}$ 3-(N-morpholino)propanesulfonic acid (Mops), $100 \mu \mathrm{M}$ phenylmethylsulfonyl fluoride, and $20 \mu \mathrm{M}$ leupeptin, adjusted to $\mathrm{pH}$ 7.2. Cells were then disrupted by sonication and extracted at $4^{\circ} \mathrm{C}$ for $30 \mathrm{~min}$. The proteins $(50 \mu \mathrm{g})$ obtained were electro-transferred to Immobilon-P membranes. PARP (1:1000), procaspase-3 (1:3000), and Mcl-1 (1 : 1000) were detected using an ECL western blotting kit (Millipore). $\beta$-Actin was used as loading control using $\beta$ Actin antibody at a dilution of $1: 2000$, and experiments were performed three times $(n=3)$. 


\section{FACS}

Subcultured SMCs were plated at $1 \times 10^{4}$ cells $/ \mathrm{cm}^{2}$ in $100 \Phi$ plates, and treated with $1 \mu \mathrm{M} \mathrm{GA}$ for $24 \mathrm{~h}$. Then, 5 $\times 10^{6}$ cells in $100 \mu \mathrm{L}$ of PBS were suspended, and $200 \mu \mathrm{L}$ of $95 \%$ ethanol was added while vortexing cells were incubated for $1 \mathrm{~h}$ at $4^{\circ} \mathrm{C}$, washed with PBS, and resuspended in $250 \mu \mathrm{L}$ of $1.12 \%$ sodium citrate buffer $(\mathrm{pH}$ 8.4) containing $12.5 \mu \mathrm{g}$ of RNase. Incubation was continued for 30 min at $37^{\circ} \mathrm{C}$. Cellular DNA was then stained by applying $250 \mu \mathrm{L}$ of PI $(50 \mu \mathrm{g} / \mathrm{mL})$ for $30 \mathrm{~min}$ at room temperature. Stained cells were analyzed by fluorescent activated cell sorting (FACS) on a BD FACS Canto II flow cytometer (BD Biosciences, San Jose, CA, USA) for relative DNA content based on red fluorescence. Cells undergoing apoptosis lose some of their DNA due to DNA fragmentation during later apoptosis. These cells were detected as a subG1 population. Experiments were performed three times $(n=3)$.

\section{Statistical analysis}

Data are presented as means \pm SDs. SPSS ver. 13.0 statistical software (SPSS, Inc., Chicago, IL, USA) was used for the analysis. Paired comparisons were performed using the Student's t-test. Statistical significance was accepted for $\mathrm{p}$ values $<0.05$.

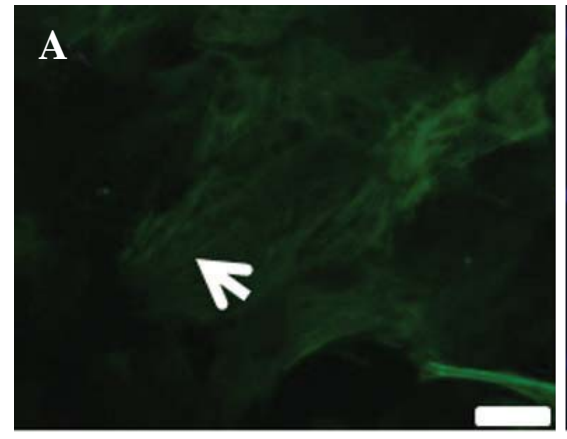

$\alpha$-SMA

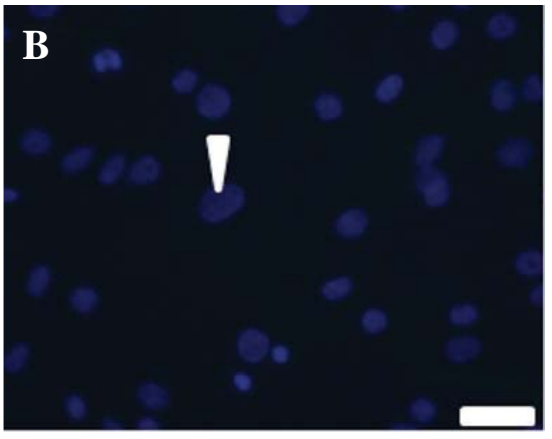

DAPI

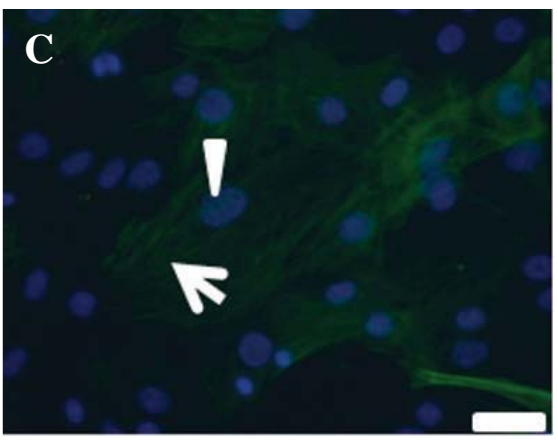

Merge

Fig. 1. Microphotographs of IF-stained SMCs against $\alpha$-SMA in the same microscopic field. Arrows indicate FITC-conjugated $\alpha$-SMA in the cytoplasm of SMCs, and arrowheads indicate nuclei counter-stained with DAPI. A; $\alpha$-SMA stained green in cytoplasm, B; nuclei of SMCs and fibroblasts are stained blue, C; merge image of $\alpha$-SMA and DAPI. Scale bars $=50 \mu \mathrm{m}$.
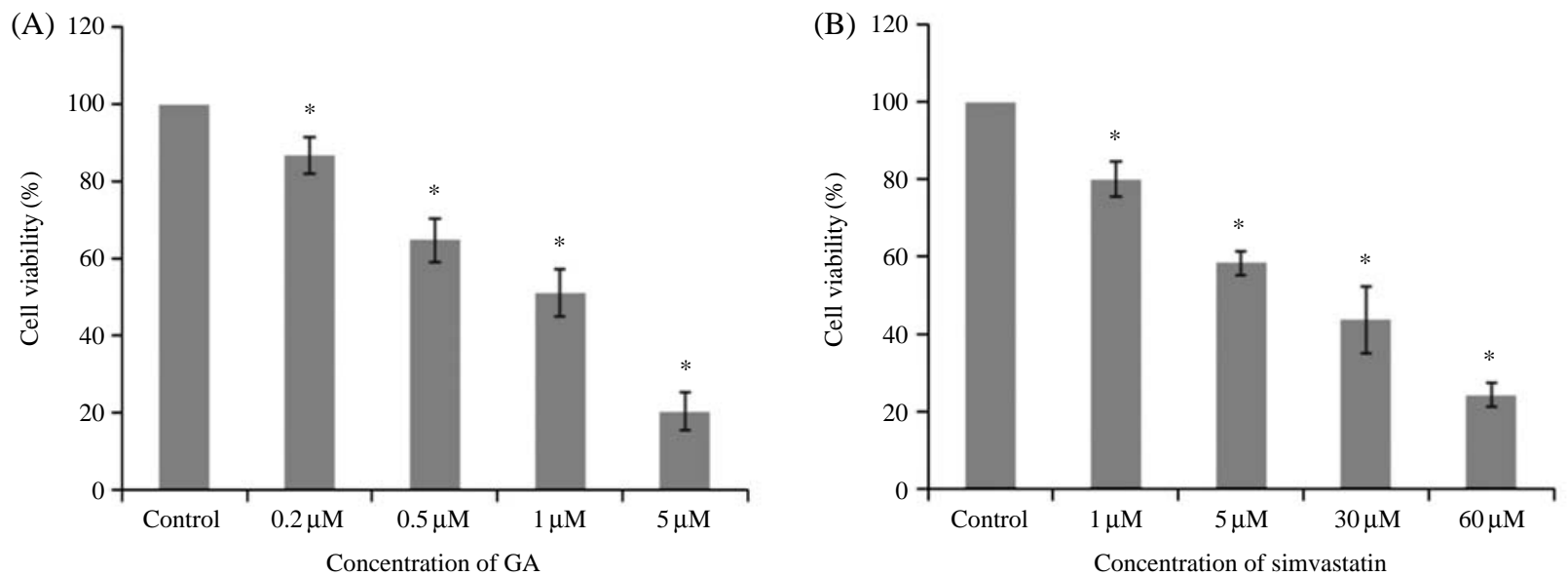

Fig. 2. Cell viability percentages after treatment with different concentrations of GA or simvastatin. SMC cell-death was promoted dosedependently by treatment with GA (A) at $0,0.2,0.5,1$, or $5 \mu \mathrm{M}$ for $24 \mathrm{~h}$, or by with simvastatin (B) at $0,1,5,30$, or $60 \mu \mathrm{M}$. $* \mathrm{P}<0.05$ $(n=3)$. 


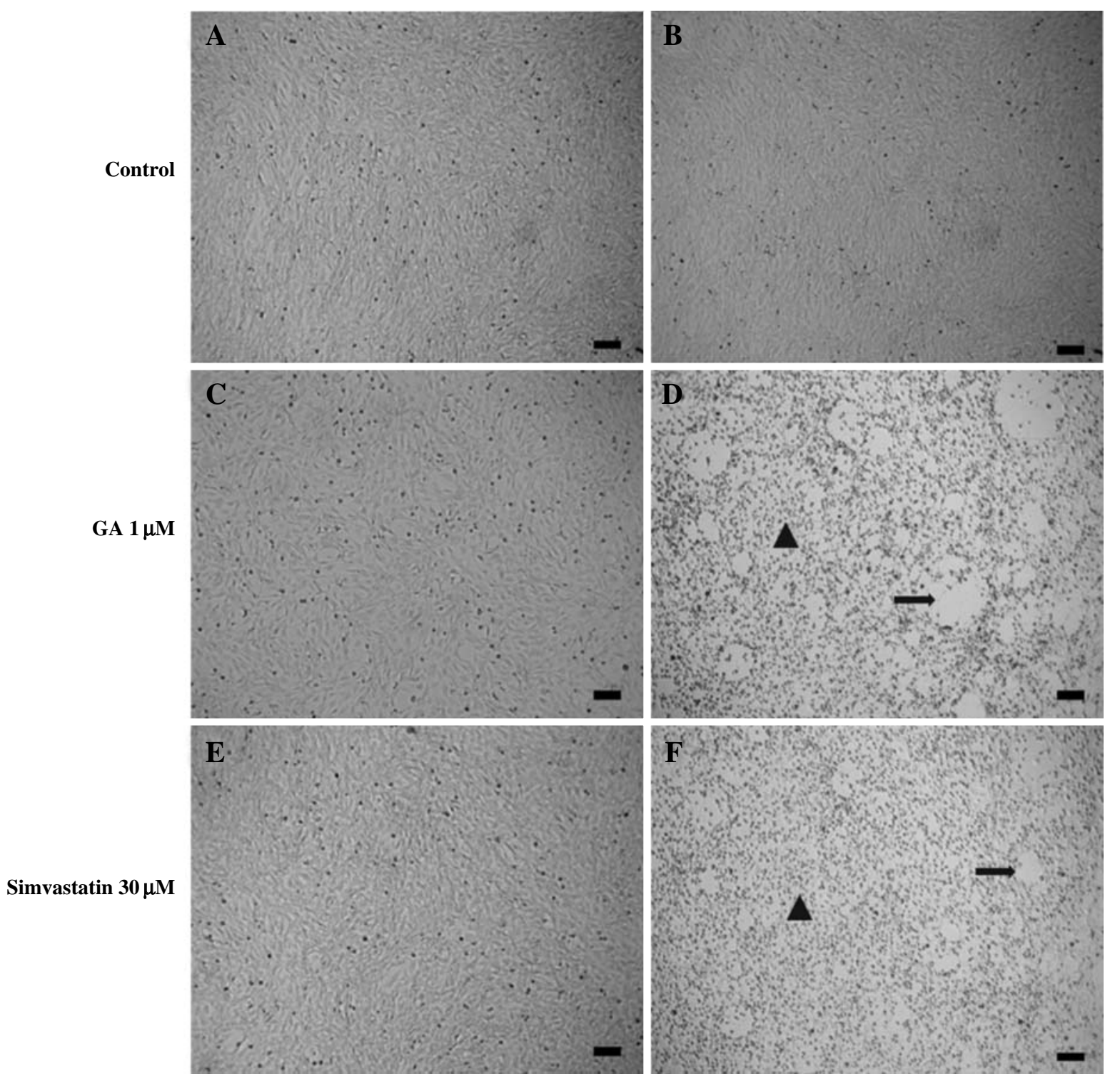

Fig. 3. Live images of SMCs grown in 96 well plates after $24 \mathrm{~h}$ of treatment. A; control at $0 \mathrm{~h}$, B; control at $24 \mathrm{~h}$, C; non-treated control at $0 \mathrm{~h}, \mathrm{D} ; 1 \mu \mathrm{M}$ GA treated SMCs at $24 \mathrm{~h}$, rounded cells (arrowhead) and voids left by detached cells (arrow), E; non-treated control at $0 \mathrm{~h}, \mathrm{~F}$; simvastatin $(30 \mu \mathrm{M})$ treated SMCs at $24 \mathrm{~h}$, rounded cells (arrowhead) and voids left by detached cells (arrow).

\section{Results}

\section{Identification of aortic SMCs using $\alpha$-SMA}

The purities of subcultured cells were determined by calculating percentages of $\alpha$-SMA positive cells among cells grown on cover glasses. $\alpha$-SMA positive cells, that is, aortic SMCs, had green cytoplasm after IF staining, whereas fibroblast cytoplasm was not stained (Fig. 1A, C). SMC and fibroblast nuclei were counter-stained blue using DAPI (Fig. 1B). Of the subcultured cells, $92.3 \pm 4.11 \%$ $(n=3)$ stained positively for $\alpha$-SMA (Fig. 1C).

\section{Cells viabilities after GA or simvastatin treatment}

To determine the $\mathrm{IC}_{50}$ values of $\mathrm{GA}$ and simvastatin, SMCs were assayed by MTT and percentage viabilities were determined at various concentrations $(0.2-60 \mu \mathrm{M})$ after exposure for $24 \mathrm{~h}$. As shown in Fig. 2B, aortic SMC viabilities were significantly and dose-dependently reduced after treatment with $0,0.2,0.5,1$, or $5 \mu \mathrm{M}$ of GA and/or $0,1,5,30$, or $60 \mu \mathrm{M}$ of simvastatin for $24 \mathrm{hrs}(\mathrm{P}<0.05$, 

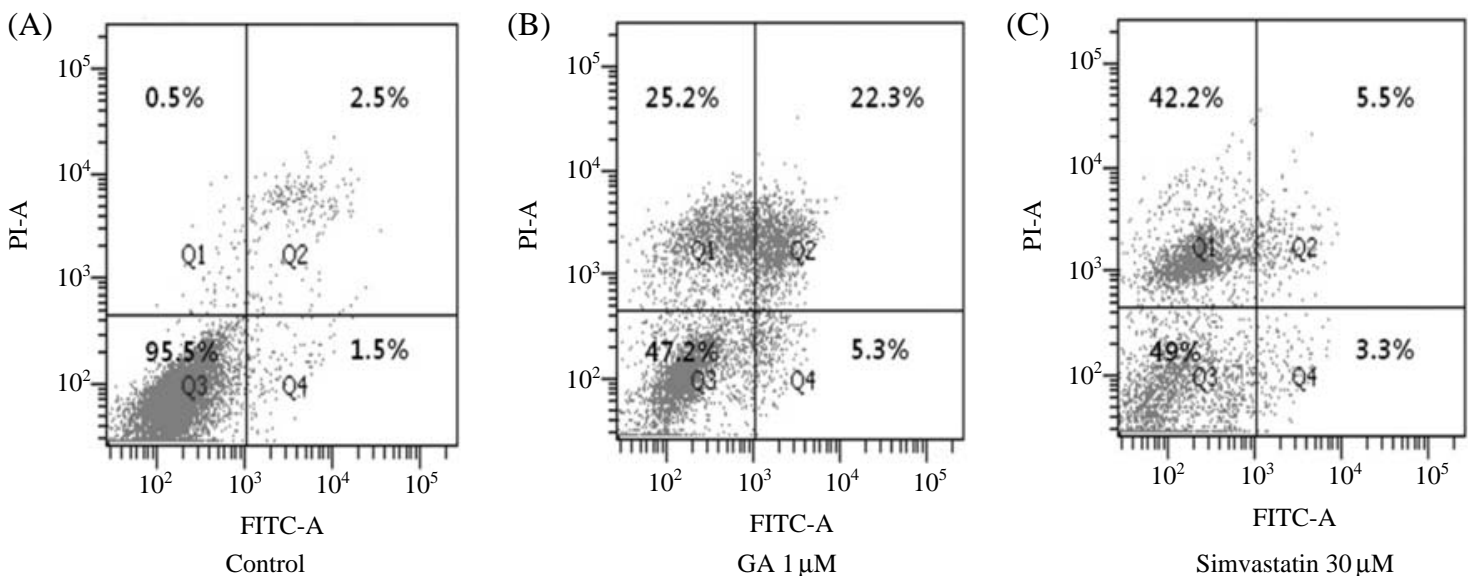

Simvastatin $30 \mu \mathrm{M}$

Fig. 4. FITC annexin-V and PI double-staining as determined using a FACScanner. Q1 represents normal SMCs, Q2 necrotic cells, Q3 early apoptotic cells, Q4 late apoptotic cells. A; non-treated control at $24 \mathrm{~h}, \mathrm{~B} ; 1 \mu \mathrm{M}$ GA treated cells at $24 \mathrm{~h}, \mathrm{C} ; 30 \mu \mathrm{M}$ simvastatin treated cells at $24 \mathrm{~h}$. The results of representative experiments are shown. Experiments were performed in triplicate.

$\mathrm{n}=3)$. The $\mathrm{IC}_{50}$ values of $\mathrm{GA}$ or simvastatin were 1 and $30 \mu \mathrm{M}$, respectively

\section{Live cell images}

Live non-treated controls were flatter (Fig. 3A, B, C, E) than cells treated with $1 \mu \mathrm{M} \mathrm{GA}$ (Fig. 3D) or $30 \mu \mathrm{M}$ simvastatin (Fig. 3F) for $24 \mathrm{~h}$. In addition, some treated cells detached from plate wells, and produced empty spaces.

\section{Analysis of apoptosis by FITC annexin-V and PI double-staining}

To test the hypothesis that GA increases cell death by inducing apoptosis, we used an Annexin-V-FITC and PI double staining technique. As shown in Fig. 4B. GA $(1 \mu \mathrm{M})$ treated aortic SMCs showed higher percentages of apoptotic cells than $30 \mu \mathrm{M}$ simvastatin-treated SMCs $(26.4 \pm$ $2.37 \%$ vs. $8.3 \pm 1.54 \%$, respectively; Fig. $4 \mathrm{~B}, \mathrm{C}$; $\mathrm{P}<0.05$, $\mathrm{n}=3$ ), whereas simvastatin-treated SMCs resulted in higher percentages of necrotic cells than GA-treated SMCs $(43.2 \pm 2.76 \%$ vs. $24.9 \pm 3.12 \%$, respectively; Fig. $4 \mathrm{~B}, \mathrm{C}$; $\mathrm{P}<0.05, \mathrm{n}=3)$.

\section{Levels of apoptosis regulating proteins}

Cells undergoing apoptosis execute the death program by activating caspases, which then cleave PARP and procaspase-3. Accordingly, we analyzed the expression levels of PARP and procaspase- 3 and levels of the cleavage products of PARP and procaspase-3. As demonstrated in Fig.

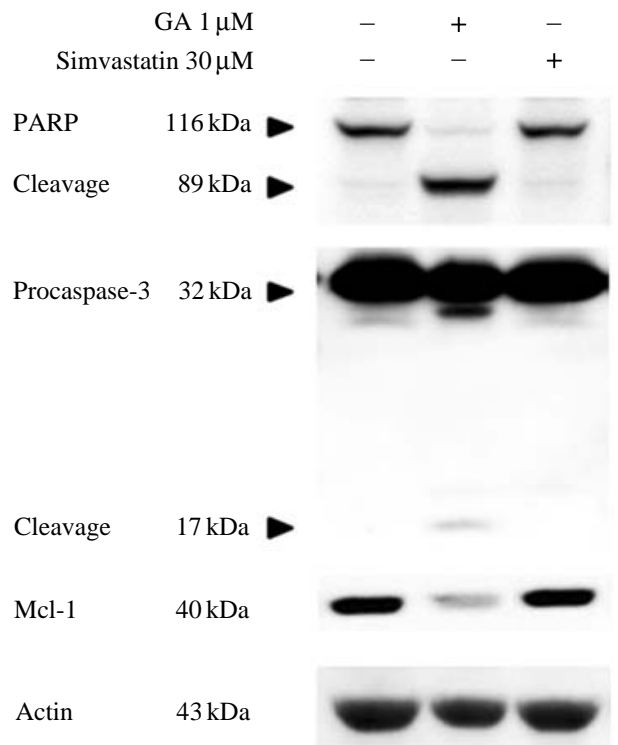

Fig. 5. The expression levels of apoptosis regulating proteins. SMCs were treated with GA or simvastatin for $24 \mathrm{~h}$ and harvested in lysis buffer. Equal amounts of cell lysates were then resolved by SDS-PAGE. Western blotting was performed using anti-PARP, -caspase-3 and -Mcl-1 antibodies and with anti- $\beta$-Actin antibody. The results of representative experiments are shown. Experiments were performed in triplicate.

5 , exposure to $\mathrm{GA}(1 \mu \mathrm{M})$ led to reductions in the $116 \mathrm{KDa}$ precursor of PARP and $32 \mathrm{KDa}$ precursor of procaspase3 , and to the concomitant cleavages of PARP and procaspase-3. To investigate the mechanism responsible for GAinduced apoptosis, we analyzed changes in Mcl-1 protein levels. Mcl-1 protein expression was decreased when 
(A)

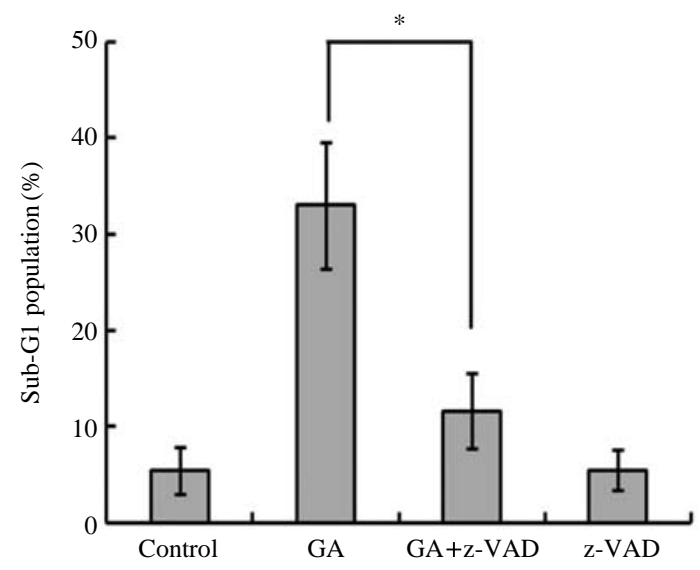

(B)

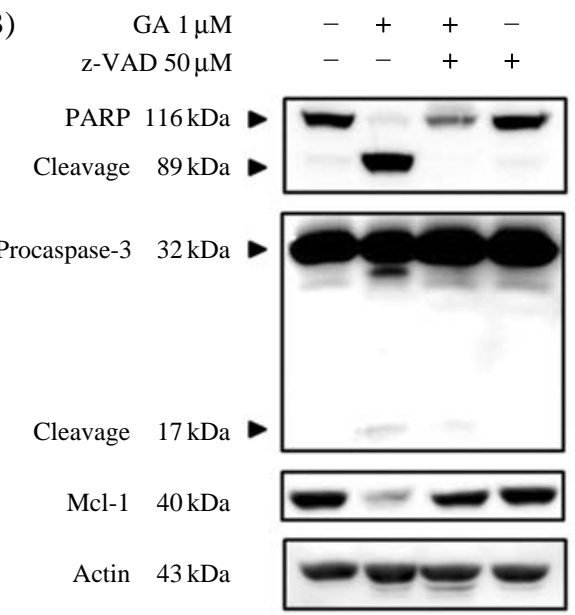

Fig. 6. z-VAD pretreatment. 6A; Effect of z-VAD-fmk on apoptosis induced by GA. SMCs were incubated with $50 \mathrm{M}$ z-VAD-fmk or solvent for $1 \mathrm{~h}$ and then treated with GA for $24 \mathrm{~h}$. The DNA contents of treated cells were evaluated after PI staining and apoptosis was determined using sub-G1 fractions as determined by FACS. ${ }^{*} \mathrm{P}<0.05(\mathrm{n}=3), 6 \mathrm{~B}$; Effect of $\mathrm{z}$-VAD-fmk on caspase activation in GAtreated cells. Equal amounts of cell lysates were subjected to electrophoresis and analyzed by Western blotting for PARP, caspase-3, and Mcl-1, and for $\beta$-Actin. The results of representative experiments are shown. Experiments were performed in triplicate.

SMCs were treated with GA at $1 \mu \mathrm{M}$. In contrast, Mcl-1 protein levels remained constant after treating cells with $30 \mu \mathrm{M}$ simvastatin (Fig. 5).

\section{6. z-VAD pretreatment}

We next examined whether activation of the caspase pathway plays a critical role in $1 \mu \mathrm{M}$ GA-induced apoptosis. As shown in Fig. 6A, GA-induced apoptosis was completely prevented by pre-treatment with z-VAD-fmk (a potent general caspase inhibitor), as determined by FACS $(\mathrm{P}<0.05, \mathrm{n}=3)$. Furthermore, $\mathrm{z}-\mathrm{VAD}-\mathrm{fmk}$ prevented all caspase-related events, such as, the cleavages of PARP and procaspase-3 (Fig. 6B). Furthermore, pretreatment with $\mathrm{z}$-VAD-fmk prevented Mcl-1 protein down-regulation by GA.

\section{Discussion}

In a preliminary study, we developed a means of harvesting aortic SMCs at relatively high purity to investigate the roles played by VSMCs during the pathogenesis of atherosclerosis [22]. In the present study, we investigated whether GA induces the apoptosis of aortic SMCs isolated from rat aortas using a simple enzymatic method [22], and compared the apoptotic potencies of GA and simvastatin.

In the present study, GA was administered to SMCs at
$1 \mu \mathrm{M}$ (its $\mathrm{IC}_{50}$ ) level as determined using the MTT assay, whereas simvastatin, which is commonly used to treat atherosclerosis, was used at its $\mathrm{IC}_{50}(30 \mu \mathrm{M})$. These $\mathrm{IC}_{50}$ values suggest that $\mathrm{GA}$ is considerably more potent than simvastatin based on SMC viability, which is not surprising because simvastatin is a cholesterol-lowering agent [20].

In the present study, live images of aortic SMCs treated with $\mathrm{GA}(1 \mu \mathrm{M})$ or simvastatin $(30 \mu \mathrm{M})$ revealed a rounder morphology and some cells detached from culture vessels. These microscopic findings suggest that both drugs have cytotoxic effects on SMCs, and this is supported by our observations of their apoptotic/necrotic effects by FITC annexin- $\mathrm{V}$ and PI double staining.

GA at $1 \mu \mathrm{M}$ resulted in more SMC apoptosis than simvastatin at $30 \mu \mathrm{M}(\mathrm{P}<0.05, \mathrm{n}=3)$, whereas simvastatin produced more necrotic cells $(\mathrm{P}<0.05, \mathrm{n}=3)$. The anticancer effect of GA has been largely attributed to its activation of impaired apoptosis pathways in cancerous cells via the down-regulation of telomerase [17]. Apoptosis is essential for arterial remodeling [24], and thus, our results suggest that $1 \mu \mathrm{M} \mathrm{GA}$ is a more potent apoptotic agent for the control of aortic SMC proliferation in atherosclerosis. In fact, $\mathrm{GA}$ at $1 \mu \mathrm{M}$ produced similar levels $(\sim 25 \%, \mathrm{n}=3)$ of apoptotic and necrotic cells, which in turn, suggests that the maximum apoptotic effect of GA might be obtained at a concentration lower than $1 \mu \mathrm{M}$ in vitro.

In the present study, $1 \mu \mathrm{M} \mathrm{GA}$ induced the cleavages of 
PARP and procaspase-3, whereas $30 \mu \mathrm{M}$ simvastatin did not, which suggests that the cleavages of PARP and procaspase- 3 are associated with caspase activation. Furthermore, pretreatment with z-VAD-fmk attenuated GA-induced apoptosis. Thus, these results indicate that GA-induced apoptosis was mediated via a caspase-dependent pathway, which is in accord with a recent reported that the cytotoxic effect of GA on neuroblastoma cells is mediated by a caspase-dependent signaling pathway [25]. In addition, pretreatment with $\mathrm{z}$-VAD-fmk prevented Mcl-1 protein downregulation by $1 \mu \mathrm{M} \mathrm{GA}$, indicating that the downregulation of Mcl-1 protein was caused by caspase activation. Inhibition of GA-induced Mcl-1 protein downregulation by zVAD-fmk is strongly supported by a report that Mcl-1 protein can be cleaved by activated caspase 3 [26]. The apoptotic effect of simvastatin in atherosclerosis is also known to involve down-regulation of $\mathrm{p} 53$ and the up-regulations of Bcl-2 and Bcl-xL [27].

Taken together, our in vitro results on rat aortic SMCs suggest that GA might be more effective than simvastatin at inducing apoptosis, which suggests that GA is a promising therapeutic proposition for the treatment of atherosclerosis. We suggest that further studies be conducted to examine the effects of GA in a disease model of atherosclerosis.

\section{References}

1. Raines EW, Ross R. Smooth muscle cells and the pathogenesis of the lesions of atherosclerosis. Br Heart J. 1993; 69: 30-7.

2. Ross R. Atherosclerosis-an inflammatory disease. N Engl J Med. 1999; 340:115-26.

3. Libby P. Inflammation in atherosclerosis. Nature. 2002; 420: 868-74.

4. Hur KY, Seo HJ, Kang ES, Kim SH, Song S, Kim EH, et al. Therapeutic effect of magnesium lithospermate B on neointimal formation after balloon-induced vascular injury. Eur J Pharmacol. 2008; 586:226-33.

5. Owens GK, Kumar MS, Wamhoff BR. Molecular regulation of vascular smooth muscle cell differentiation in development and disease. Physiol Rev. 2004; 84:767-801.

6. Newby AC, George SJ. Proliferation, migration, matrix turnover and death of smooth muscle cells in native coronary and vein graft atherosclerosis. Curr Opin Cardiol. 1996; 11:574-82.
7. Thyberg J, Blomgren K, Roy J, Tran PK, Hedin U. Phenotypic modulation of smooth muscle cells after arterial injury is associated with changes in the distribution of laminin and fibronectin. J Histochem Cytochem. 1997; 45:837-46.

8. Schwartz SM, deBlois D, O'Brien ER. The intima. Soil for atherosclerosis and restenosis. Circ Res. 1995; 77:445-65.

9. Stiles CD, Capone GT, Scher CD, Antoniades HN, Van Wyk JJ, Pledger WJ. Dual control of cell growth by somatomedins and platelet-derived growth factor. Proc Natl Acad Sci USA. 1979; 76:1279-83.

10. Raines EW. PDGF and cardiovascular disease. Cytokine Growth Factor Rev. 2004; 1: 237-54.

11. Osada-Oka M, Ikeda T, Imaoka S, Akiba S, Sato T. VEGFenhanced proliferation under hypoxia by an autocrine mechanism in human vascular smooth muscle cells. J Atheroscler Thromb. 2008; 15:26-33.

12. Holm PW, Slart RH, Zeebregts CJ, Hillebrands JL, Tio RA. Atherosclerotic plaque development and instability: a dual role for VEGF. Ann Med. 2009; 41:257-64.

13. Ross R. Cell biology of atherosclerosis. Annu Rev Physiol. 1995; 57: 791-804.

14. Ross R. Mechanisms of atherosclerosis-a review. Adv Nephrol Necker Hosp. 1990; 19:79-86.

15. Blum A, Miller HI. The role of inflammation in atherosclerosis. Isr J Med Sci. 1996; 32:1059-65.

16. Bochaton-Piallat, Gabbiani F, Redard M, Desmoulière A, Gabbiani G. Apoptosis participates in cellularity regulation during rat aortic intimal thickening. Am J Pathol. 1995; 146: 1059-64.

17. Guo QL, Lin SS, Youb QD, Gua HY, Yua J, Zhaoa L, et al. Inhibition of human telomerase reverse transcriptase gene expression by gambogic acid in human hepatoma SMMC7721 cells. Life Sci. 2006; 78:1238-45.

18. Kasibhatla S, Jessen KA, Maliartchouk S, Wang JY, English NM, Drewe J, et al. A role for transferrin receptor in triggehring apoptosis when targeted with gambogic acid. Proc Natl Acad Sci USA. 2005; 102:12095-100.

19. Pandey MK, Sung B, Ahn KS, Kunnumakkara AB, Chaturvedi MM, Aggarwal BB. Gambogic acid, a novel ligand for transferrin receptor, potentiates TNF-induced apoptosis through modulation of the nuclear factor-kB signaling pathway. Blood. 2007; 110:517-25.

20. Li Z, Yang YJ, Qin XW, Ruan YM, Chen X, Meng L, et al. Effects of tongxinluo and simvastatin on the stabilization of vulnerable atherosclerotic plaques of aorta in aortic atherosclerosis and molecular mechanism there of: a comparative study with rabbits. Zhonghua Yi Xue Za Zhi. 2006; 86: 3146-50. Chinese.

21. Hernández-Perera O, Pérez-Sala D, Navarro-Antolín J, Sánchez-Pascuala R, Hernández G, Díaz C, et al. Effects of 
the 3-hydroxy-3-methylglutaryl-CoA reductase inhibitors, atorvastatin and simvastatin, on the expression of endothelin-1 and endothelial nitric oxide synthase in vascular endothelial cells. J Clin Invest. 1998; 15:2711-19.

22. Kim KG, Sung EG, Kim JY. An effective isolation of the vascular endothelial and smooth muscle cells from the mouse aorta. Korean J Anat. 2009; 42:93-104. Korean.

23. O'Sullivan M, Scott S, McCarthy N, Shapiro LM, Kirkpatrick PJ, Bennett MR. Differential cyclin E expression in human in stent stenosis vascular smooth muscle cells identifies targets for selective anti-restenotic therapy. Cardiovasc Res. 2003; 60:673-83.

24. Chen L, Gao W. 4-(methylnitro-samino)-1-(3-pyridyl)-1butanone induces CRM1-dependent p53 nuclear accumula- tion in human bronchial epithelial cells. Toxicol Sci. 2010; 116:206-15.

25. Rahman MA, Kim NH, Huh SO. Cytotoxic effect of gambogic acid on SH-SY5Y neuroblastoma cells is mediated by intrinsic caspase-dependent signaling pathway. Mol Cell Biochem. 2013; 377(1-2):187-96.

26. Weng C, Li Y, Xu D, Shi Y, Tang H. Specific cleavage of Mcl-1 by caspase-3 in tumor necrosis factor-related apoptosis-inducing ligand (TRAIL)-induced apoptosis in Jurkat leukemia T cells. J Biol Chem. 2005; 280:10491-500.

27. Qin W, Lu Y, Zhan C, Shen T, Dou L, Man Y, et al. Simvastatin suppresses apoptosis in vulnerable atherosclerotic plaques through regulating the expression of p53, Bcl-2 and Bcl-xL. Cardiovasc Drugs Ther. 2012; 26:23-30. 


\title{
Gambogic acid에 의해 유도된 caspase 의존성 경로 활성화를 통한 대동맥 민무늬근육세포의 사멸
}

\author{
김대광 ${ }^{1,2}$, 이태진 ${ }^{3}$, 김은애 $^{3}$, 강주환 $^{3}$, 김경 곤 $^{3}$, 김주영 ${ }^{3}$
}

${ }^{1}$ 계명대학교 의과대학 의학유전학교실, ${ }^{2}$ 한빛의학유전학연구소, ${ }^{3}$ 영남대학교 의과대학 해부학교실

간추림 : Gambogic acid $(\mathrm{GA})$ 는 강력한 항암효과를 가진다. 민무늬근육세포의 증식과 이동은 죽상동맥경화증의 발병기전에 있어 중요한 역할을 한다. 이 연구는 GA가 대동맥 민무늬근육세포에 대하여 세포사멸 효과가 있는 지를 조사하였고, simvastatin에 비해 GA의 효과가 얼마나 유용한지를 연구하였다.

대동맥 민무늬근육세포는 4-6주 된 Sprague-Dawley 흰쥐에서 분리하였다. 이들 세포는 민무늬근육의 $\alpha$-액틴 항체로 면역형광염색법으로 확인하였다. $\mathrm{MTT}$ 방법으로 $\mathrm{GA}$ 와 simvastatin의 $\mathrm{IC}_{50}$ 을 결정하였다. 약제 각각의 $\mathrm{IC}_{50}$ 으로 24 시간 처리한 후, 살아있는 세포영상 분석, 형광물질이 표지된 annexin $\mathrm{V}$ 와 propium iodide로 이중염 색하여 세포사멸 정도 분석을 각각 시행하였다. 또한, western blot으로 민무늬근육세포에서 PARP 및 procaspase-3의 감소와 PARP 및 procaspase-3의 분할을 보고, 세포사멸임을 검증하였다.

$\mathrm{GA}$ 의 $\mathrm{IC}_{50}$ 인 $1 \mu \mathrm{M}$ 은 simvastatin의 $\mathrm{IC}_{50}$ 인 $30 \mu \mathrm{M}$ 보다 낮았는데, 이는 $\mathrm{IC}_{50}$ 만으로 보았을 때 $\mathrm{GA}$ 가 simvastatin 보다 더 강력한 약제임을 보여주었다. 또한 세포영상에서 약제종류와는 상관없이 약제처리 24시간 후, 처리하지

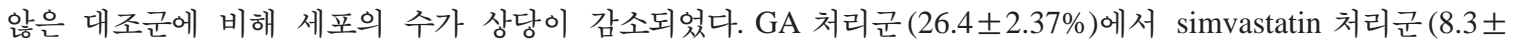
$1.54 \%)$ 에 비해 세포사멸된 세포들이 더 높은 백분율을 나타냈다 $(\mathrm{P}<0.05, \mathrm{n}=3)$. 또한 $\mathrm{GA}$ 를 처리하면 PARP, procapase-3, 그리고 Mcl-1의 발현을 감소시켰지만, simvastatin을 처리 한 경우에는 없었다. z-VAD-fmk로 전처 리 후, PARP와 procaspase-3의 분할 뿐만 아니라 GA에 의해 유도된 세포사멸이 감쇄되었다. GA에 의해 유발 된 Mcl-1 단백질 발현의 감소는 z-VAD-fmk에 의해 복구되었다.

이들 결과는 GA에 의해 유도된 세포사멸이 caspase 의존성 경로를 통해 일어난다는 것을 의미한다.

찾아보기 낱말 : gambogic acid, 세포사멸, 민무늬근육세포, simvastatin 